\title{
INTEGRATING MOBILE PHONES IN ENGLISH LANGUAGE TEACHING: A STUDY IN MANIPUR UNIVERSITY
}

\author{
Irom Gambhir Singh
}

The advancement of Information and Communication Technology (ICT) has great impact on students' accessibility to information and different source materials. With the rapid development of modern science and technology, mobile devices have undergone massive changes and it has become so advanced that they can perform almost all the functions of a computer. Cell phones can be used for learning purposes. The present paper discusses possible future applications of cell phones for English language teaching and learning in Manipur University. The data was obtained from a set of questionnaires sent to selected students to find out their attitudes towards this mode of teaching English language. The analysis revealed that students use mobile phones to help them in their studies and they believe that integrating mobile phones in a language teaching gives the learners the opportunity of availing the benefits of digital age. They also believed that cell phones have great potential in language teaching and learning.

Keywords: M-Learning, Mobile Phones, Information and Communication Technology for learning, English Language Teaching

\section{Introduction}

The impact of globalization in recent decades led to the accessibility of technological devices, not only in the metropolis of developed countries but also in the rural areas of developing ones. In the past few decades, mobile devices played important roles in the rapid progress and development of modern science and technology. There are currently several types of mobile devices that are in use. Some of them are Personal Digital Assistants (PDAs), IPods, tablets, cell phones, mp3 or mp4 players, cameras, recorders etc. Among all the mobile devices, cell phones are probably the most popular and widely used all over the world. Cell phones are making our lives easier and people are so accustomed to them that it is hard to imagine life without cell phones. Some cell phones are so developed and so advanced that they can even perform almost all the functions of a computer. They are not used only as communication devices but are used like mini computers that can be carried anywhere anytime. Cell phones can be used for learning purposes. The attitude of the students of Manipur University towards mobile phones is very positive. Though most of the time they use it for recreational purposes.

Most people use cell phones as a communication or recreational tool as opposed to learning and studying. But in European countries mobile learning has developed immensely. Unfortunately it is yet to be developed in South Asia, particularly in India. This paper is an exploratory study on learners' perception to mobile learning and it discusses possible future application of cell phones in ESL (English as a Second Language) learning in Manipur, a north eastern state of India. As people have started using latest mobile devices, they can learn whenever and wherever they may be. Moreover mobile devices provide individuals with abundant information and materials related to any topic. Whether the present pedagogical condition at Manipur University supports cell phone or smart phone as a language learning tool or not, is really a considerable matter. The current study is designed to explore learners' attitude to mobile phone or cell phone use as an instructional tool in the context of Manipur University.

\section{Mobile Assisted Language Learning}

Mobile assisted Language Learning (MALL) describes an approach to language learning that is enhanced through use of a mobile device. MALL is a subset of both Mobile Learning (m-learning) and Computer-assisted language learning (CALL). MALL is involved with the use of the mobile technologies, such as mobile phones, MP3

Nepalese Linguistics, vol. 34, 2019, pp. 68-72. 
/MP4 players, PDAs and palmtop computers, to support students' language learning. With MALL students are able to access language learning materials, and to communicate with their teachers and peers, at anytime, anywhere (KukulskaHulme, 2006 quoted in Begum, 2014). Prensky observes that the browser in web-enabled phones puts a dictionary, thesaurus and encyclopedia into the hand of every student: access to Google and other text search engines turns their cell phones into research tools. (cited in Meurant, 2015). Relating to the clarification of ICT, Ibrahim (2010) illustrates that it is the term that is currently used worldwide to describe new technologies that depend mainly on computer and the internet. Even the traditional technologies such as radio, television and telephone are considered as ICTs. In accordance with the United Nations Development Program (UNDP, 2003), ICTs include, 'basically information -handling tools-a varied set of goods, applications and services that are used to produce, store, process, distribute and exchange information.

Cell phones have become increasingly sophisticated and they are developed to have computer like functions. It is convenient to carry around and it can be used not only to make calls, but browse online, downloads, send and receive mails, play music, record videos and audios, play games etc. But before cell phones are introduced as a device for teaching and learning in a classroom a thorough look and analysis of the basic functions of cell phones is necessary.

Voice: The basic function of cell phones is to communicate. People all around the world are using cell phones to communicate and they spend a considerable amount of time talking in cell phones. It is very important to make calls in this busy world instead of wasting valuable time going to meet a person. In some mobile apps like WhatsApp, people can record their voice and send as a voice note. The receiver can listen to the notes at their own leisure time. Moreover, learners can record their voice and listen to it later and find out areas they need to improve on.

SMS (Short Message Service): SMS is a service that allows people with cell phones to send text messages as opposed to talking. SMS is another option to communicate without using voice. Sending messages is preferable in certain context as people feel more relaxed and they have more time to think what they want to communicate. Moreover, sending messages is cheaper than making calls.

Browsing: It is very convenient for students to browse using cell phones. They can read relevant materials for their studies online. They can also check e-mails, read e-books, instructional materials and watch lecture videos from anywhere in the world.

Downloading: It is very convenient for students to download easily various kinds of materials using their cell phones. Many free online books and materials that can be used for learning English are available to download. Students can download the required e-books and read them anywhere or anytime they find convenient. They do not have to worry about carrying their heavy textbooks. Students can also download useful software and also dictionaries. Downloaded materials could be shared by teachers to their students and students can share with their friends and learn together.

Camera: Students will benefit greatly by having a camera on the cell phone while collecting data, documenting information and storing visual information. Students can take pictures from their mobile camera of texts they want to read and read later at their own leisure time.

Gaming: The game feature is available in almost every cell phone. There are many instructional games available that will develop the thinking skills, decision making skills and also help in developing problem solving skills. It is also a tool for relaxation and people learn a lot through playing games.

With the prevalence of mobile phones and its easy access to information, educators need to review their approaches to pedagogy and try to incorporate phones in their teaching. Focus should be given to use the facilities of mobile technologies in teaching and learning process so that teaching becomes more effective and enjoyable. This study examines the students' perception of the use of mobile technologies in 
70 / Integrating mobile phones...

teaching and learning of English in Manipur University.

Majority of the students in the University campus of Manipur have mobile phones. Students are seen having a quick conversation about classes or assignments or silently texting offline or online messages while some others are engaged in reading e-mails. Students are quick to adopt the mobile technology that allows them to keep in touch with friends and access the net as they move on with their daily routine. Given the popularity of the mobile phones in the university campus this is a study to find out how it can be utilized for educational purposes.

\section{Defining Mobile Learning}

Teaching and learning through Mobile Technologies (MT) is called M-learning. It allows learning in no fixed location or time of learning (Kinshuk, 2003 cited in Abimbola, 2013). Trifonova and Ronchetti (2003 as cited in Suleiman, 2011) state that Mobile Learning is "elearning through mobile computational devices". According to Vavoula and Sharples ( as cited in Maryam Tayebinik, 2012), learning can be considered mobile in three different contexts: learning is mobile in regard to space, it is mobile due to the different places, and it is mobile in terms of time. Therefore, mobile learning system can deliver education anytime anywhere and, if this technology is adopted, it will benefit the learners because education or interaction with the teacher does not occur only in the classroom. The learners could be at home relaxing yet be actively involved in learning.

Majority of students and teachers in the University has access to mobile phones. Many people used mobile as communication or recreational devices and there is little awareness in the students that it could be used for learning. But like all communication and computing devices, cell phones, can be used to learn (Prensky, 2004 as cited in Begum, 2014). Various facilities offered by the mobile phones need to be pointed out and instructed to utilize so that benefits will be gathered by the students.

Most of the students in the University do not own a personal computer and it is not easy to have computer always within the reach. But mobile phones are inseparable with everyone nowadays, especially the students. Cell phones have been developed to a great extent and this facility could be used in ESL classroom to teach English. Educators can take advantage of the cell phones popularity to incorporate it in their teaching.

Schools and institutions have restrictions regarding cell phones in the campus. But in the University campus there is no restriction of using cell phones. Considering the great advantages cell phones can bring, educators can encourage the learners to use it for educational purposes instead of using it just for making calls, sending texts or listening to music and playing games. Teachers' familiarity with the functions of the device and its educational value can enhance the potentiality of mobile phones as a learning tool. They should be the ones to instruct the students on how to use the technology in class. Students should have the basic skills in using technologies and they should be guided to use the options available in their mobile. They should be assisted to download software and materials needed for their works. Teachers can also share files to their students through Bluetooth or Zapya.

\section{Disadvantages of Mobile Phones in English classrooms}

Though mobile phones have great unique features and functions, they are not free of disadvantages. Mobile phones have limited storage space and it has slow processing speed. The limited battery also does not hold for a very long time. Phones equipped with latest technologies do not come cheap. Moreover, technology advances very quickly and to keep up with it one has to upgrade his or her phone frequently. To have an internet connection one needs to pay a monthly data charges and to download large files, the monthly charges could be quite high. The screen size is small and so the information that can be displayed on the screen at one time is quite small. These flaws should not be overlooked but explored when accessing cell phones potential. Use of mobile phones in the classroom may cause distraction and students may start using it for non-academic purposes. So this type of learning can be conducted in a tutorial class in a tutored setting. 


\section{Methodology}

The data for this paper was obtained through questionnaires administered to twenty students studying masters in English department in Manipur University through WhatsApp. These students have smart phones and have access to internet. The participants were asked some questions and they were instructed to reply through online texts. Mobile phones are not yet incorporated in English teaching in Manipur. So the students were asked if they think mobile phones would assist them to improve their language skills and if they want to introduce mobile learning in their English language learning in the future or not. This study explores students' experience of using mobile phones for educational purposes especially for learning English. The basic purpose of the study is to find out the students perception to the adoption of mobile phones for English language learning.

\section{Discussions of Findings}

Majority of the students agree that mobile learning is a new thing for them and that they believe that if implemented will benefit them in many ways. The study revealed that most of the students use internet to get materials and information and they find mobile internet very useful. Sixteen of them have dictionary installed on their phones and they find it very useful to learn new words while four students do not have dictionaries on their phone. Eighteen students responded that they use both English and mother tongue to send messages while two of them said they use only English. Sixteen of them responded that as most of the conversations are in English they find some improvements in their language skills after sending text messages while the remaining four students are not sure. Using the T9 spell check in the phone for sending messages thirteen students find improvement in their spellings. Most of the students agree that they want to use their mobile phones for academic purposes. However there are few students who expressed their negative attitudes to the use of mobile phone for English language learning.

\section{Conclusion}

Mobile learning is still not yet implemented in Manipur University because the traditional method of teaching is still in practice. But from the study conducted among the University students it can be concluded that the students are in favour of new methods of learning and they feel that from mobile learning they can learn English better. Educators are required to be positive about the use of mobile phones for learning. Students also feel that teachers should encourage the learners to use mobile phones so that they can make classroom teaching more lively and interesting. The study reveals educational institutions must go with the need of learners' demand for 21st century technological advancement. Mobile technologies are developing rapidly in India, so we need to make good use of this by developing cell phones as educational tools. The University is a fitting place to introduce students to mobile learning, as almost all the students have cell phones and they have at least the basic knowledge of the mobile devices. Considering the fact that almost all the students in the University have mobile phones equipped with various applications for English learning like dictionary, thesaurus, T9 spell check etc. If the functions and capacities of cell phones are used for language teaching and learning effectively it offers the learners more effective ways to practice English and they benefit a lot through it.

\section{References}

Abimbola, O Ogunguyile. (2013). Towards the Integration of Mobile Phones in the Teaching of English Language in Secondary Schools in Akure, Nigeria. Theory and Practice in Language Studies. Vol. 3, No. 7, pp. 11491153. Retrieved April 21, 2015 from http://www.connection.ebscohost.com

Ahmadi, M. R. (2018). The Use of Technology in English Language Learning: A Literature Review. International Journal of Research in English Education, 3 (2), 115-125. Retrieved from: www.ijreeonline.com

Begum, Roksana. Prospect for Cell Phones as Instructional Tools in the EFL Classroom: A Case Study of Jahangirnagar University, Bangladesh. English Language Teaching vol 
72 / Integrating mobile phones...

4, No 1, March 2011. Retrieved April 24, 2015 from http://www.ccsenet.org/elt

Cui Guoqiang and Shuyan Wang. Adopting Cell Phones in EFL Teaching and Learning. Journal of Educational Technology Development and Exchange. Retrieved April 21, 2015 from http://www.//166.111.9.196/evaluate/downloa dArticle.do?articleld $=2152$

Khrisat, Abdulhafeth A and Salameh Saleem Mahmoud. Integrating Mobile Phones into the EFL Foundation Year Classroom in King Absulaziz University/ KSA: Effects on Achievement in General English and Students' Attitudes. Retrieved April 21, 2015 from http://www.//dx.doi.org/10.5539/elt.v6n8p162

Mehta, Naveen k. (2012) Mobile Phone Technology in English Teaching: Causes and Concerns. MJAL 4:2 Summer 2012. Retrieved April 21, 2015 from http://www.aedmoodle.ufpa.br/pluginfile.php? ...forum $\% 2$ Fattachment $\% 2$ F $240 \ldots$

Meurant, Robert C. Cell Phones in the L2

Classroom: Thumbs up to SMS A literature review, with implications for SLA pedagogy. . Retrieved April 21, 2015 from http:www.//homepage.mac.com/rmeurant/

Suleiman, Al Aamri Kamla. (2011). The Use of Mobile Phones in Learning English Language by Sultan Quaboos University Students: Practices, Attitudes and Challenges. Canadian Journal on Scientific and Industrial Research vol. 2, No. 3, March 2011. Retrieved April 21, 2015

from

http://www.stu.westga.edu/ bthibau1/MEDT \%20Baylen/.../13.pdf

Tayebinik, Maryam and Puteh Marlia. (2012). Mobile Learning to Support Teaching English as a Second Language. Journal of Education and Practice. Retrieved April 21, 2015 from http://www.iiste.org/Journals/index.php/JEP/ar ticle/viewFile/1850/1805. 